\title{
POZNAWANIE SCHELERA
}

\author{
„Jede Art von Erkenntnis wurzelt in Erfahrung”1.
} Max Scheler

\section{Wstęp}

Podany jako motto cytat z Maxa Schelera (1874-1928) głosi, że „każdy rodzaj poznania jest zakorzeniony w doświadczeniu". Teza ta posłużyła za punkt wyjścia do sporządzenia niniejszego artykułu, które stanowi retrospekcję konkretnych etapów refleksji nad postacią niemieckiego myśliciela. Celem nie jest ukazanie specyficznego problemu w jego spuściźnie, lecz egzemplifikacja trudności, z jakimi może się spotkać adept filozofii w konfrontacji z życiem oraz ideami uczonego. Scheler stworzył wiele dzieł, ponadto doczekał się kilku opracowań, nie wspominając już o opinii uznanego etyka i aksjologa. Oś poniższych rozważań stanowi człowiek, by posłużyć się metaforą muzyczną: począwszy od dysonansu biograficznego poprzez polifonię opracowań aż po poszukiwanie harmonii w pierwszej doniosłej monografii niemieckiego filozofa. $Z$ perspektywy tezy wyjściowej strukturę prezentowanego przyczynku można opisać jako historię poznawania postaci zaczynającą się od uwzględnienia doświadczeń osób, które ją znały. Kolejny etap to percepcja tego, jak inni pojmowali jego poznawanie. Kończy się zaś on zgłębianiem myśli Schelera poprzez refleksję nad konkretnym dziełem. Celem artykułu pozostaje natomiast uwypuklenie nieprzystawalności biografii niemieckiego myśliciela do założeń jego etyki. Choć on sam nigdy nie twierdził, że jest ideałem, to jednak formułował zasady obowiązujące wszystkich ludzi. Albo więc w swojej teorii dopuszczał wyjątki, albo zadowalał się etycznie wątpliwą hipokryzją.

\section{Poszukiwania biograficzne}

Początkiem konfrontacji z życiem oraz myślą wybranego myśliciela jest najczęściej wiedza czerpana z opracowań encyklopedycznych i podręczników historii umiłowania mądrości. Najprostszy biogram wydaje się prezentować następująco: „Studiował filozofię, psychologię i medycynę w Monachium, Berlinie i Jenie [...].

M. Scheler, Der Formalismus in der Ethik und die materiale Wertethik. Neuer Versuch der Grundlegung eines ethischen Personalismus, Halle a.d. Saale 1916, s. 163; por. także A. Węgrzecki, Przedmowa, w: M. Scheler, Wolność, miłość, świętość, tłum. G. Sowiński, Kraków 2004, s. 7. 
[W tej ostatniej] uzyskał doktorat w 1897 [...], a w 1899 habilitował się [...]. Jako docent prywatny rozpoczął działalność w Jenie, kontynuował ją na Uniwersytecie Monachijskim (1906-1910). Zainteresowany ideami fenomenologii, przyłączył się do «monachijskiej grupy fenomenologów» [...]. Przez pewien czas przebywał w Getyndze i Berlinie. W czasie wojny pogłębił swoje związki z katolicyzmem, które w latach powojennych okazały się jednak nietrwałe [...]. W 1919 objął Katedrę Filozofii na Uniwersytecie w Kolonii, został także dyrektorem Instytutu Badawczego Nauk Społecznych. Wówczas intensywniej zajął się problematyką socjologiczną [...]. Kilka miesięcy przed śmiercią objął Katedrę Filozofii we Frankfurcie nad Menem"2.

Już przy pierwszym czytaniu uderza wielość miejsc i rozległość zainteresowań filozofa. Uważniejsza lektura oraz skupienie uwagi na poglądach i autorytetach może budzić wrażenie pewnej niestałości, zarówno światopoglądu, jak i sposobów argumentacji, które przechodzą zaskakującą ewolucję od noblisty Rudolfa Euckena (18461926) poprzez fenomenologię Edmunda Husserla (1859-1938) po idealizm Georga Wilhelma Hegla (1770-1831). Także kariera akademicka nie przebiegała ani gładko, ani nieprzerwanie (1907-1910). Jedynie kreatywność pisarska autora zdaje się niewyczerpana, aczkolwiek nigdy nie ukończył swego monumentalnego dzieła finalnego ${ }^{3}$.

Laudacje na temat wiekopomnego dorobku, takie jak poniższa: „Myśliciel ten był osobowością niezwykle wrażliwą na egzystencjalne i światopoglądowe problemy człowieka. Analizował niemal wszystkie najbardziej fundamentalne zjawiska związane z ludzkim losem, zapowiadając tym egzystencjalizm i przygotowując grunt pod refleksję egzystencjalistów. Jako jeden z najbardziej wnikliwych filozofów ludzkiego losu [...]"4 prowokuje niemalże pytanie o to, jak sam żył, jak jego refleksja przetrwała biograficzny egzamin przełożenia na praktykę.

Opracowania naukowe starają się nie wychodzić poza sferę faktów historycznych oraz spisanych poglądów, jednak w kontekście życiorysu etyka i aksjologa mogą niepokoić fragmenty, które znalazły się w biografii innego adepta fenomenologii, skądinąd przyjaciela omawianego myśliciela - Dietricha von Hildebranda (1889-1977), który „z upływem czasu [...] widział coraz wyraźniej tragiczną rozbieżność pomiędzy geniuszem Schelera a jego infantylną, drażliwą i kapryśną osobowością. Pomiędzy zdumiewającymi talentami Schelera a jego całkowitym brakiem samokontroli rozciągała się przepaść. Poddawał się każdej zachciance i pragnieniu, był nałogowym palaczem, uzależnionym od kawy i aspiryny, i nie mógł czy nie

2 A. Węgrzecki, Scheler, Max, w: Powszechna encyklopedia filozofii, t. 8, red. A. Maryniarczyk, Lublin 2007, s. 941-942.

3 Por. J. Galarowicz, Max Scheler, Kraków 2019, s. 10-15; M. Uliński, Scheler, Max, w: Filozofowie współcześni. Leksykon, red. J. Szmyd, Bydgoszcz-Kraków 2003, s. 440-444; A. Węgrzecki, Scheler, Max, art. cyt.; W. Tatarkiewicz, Historia filozofii, t. 3, Historia XIX w. i współczesna, Warszawa 1950, s. 301.

4 J. Galarowicz, Max Scheler, dz. cyt., s. 8-9. 
chciał się przed tym powstrzymać”. Ponadto „był owładnięty przez swoje arbitralne nastroje. Ktoś mógł wzbudzić jego zainteresowanie na chwilę, ale kiedy uważał, że zna już tę osobę, zainteresowanie gasło. Wykazywał niewielką stałość, jeśli w ogóle ją miał, i wobec tego szybko tracił zainteresowanie także kobietami, które zdobył. Bawiąc się w ludzkim zoo, chciał zmiany i różnorodności [...]. Był człowiekiem ogarniętym namiętnościami seksualnymi, gdyż nigdy nie nauczył się panować nad swoimi pragnieniami, nawet tymi najbłahszymi. Był postacią tragiczną, ewidentnie swoim największym wrogiem, rozdartym pomiędzy tym, co wiedział, że jest dobre, a swoimi niekontrolowanymi impulsami"6. Aczkolwiek niemiecki uczony potrafił wykazać się też konsekwencją: „miał jedną podstawową zasadę, którą rygorystycznie stosował. «Nie chcę traktować siebie pedagogicznie», co znaczyło w zasadzie: "Chcę ulegać moim życzeniom i zachciankom i absolutnie odmawiam panowania nad moją naturą i temperamentem»" Scheler, który miał w sobie jakiś rys sadystyczny, znajdował przyjemność w doprowadzaniu Husserla do nerwowego zachowania. Omawiając narodziny nowego czasopisma, nieustannie przewracał strony książki Theodora Lessinga, gdzie ten opowiadał, jak w czasie wizyty, jaką złożył Husserlowi jakiś czas wcześniej, Husserl próbował wyprzeć się swojego żydowskiego pochodzenia. Scheler wiedział o tym fragmencie i delektował się zażenowaniem Husserla i jego obawą, że mógłby go znaleźć. Było to charakterystyczne dla Schelera, ale z pewnością dość niemiłe, jakkolwiek godne pożałowania było zachowanie Husserla"

Powyższy portret myśliciela charakteryzującego się emocjonalną niedojrzałością, rozwiązłością, brakiem opanowania oraz samodyscypliny jest nacechowany przede wszystkim brakiem rudymentarnego szacunku dla drugiego człowieka. Uznanie tej sytuacji za tragizm czy też farsę zależy od interpretacji. W obu przypadkach wszelka aksjologia i etyka autorstwa Schelera stają się niestety albo nieosiągalnym ideałem, albo czczym pustosłowiem. Już nie tylko „moralność samego obowiązku, pracy, punktualności, legalizmu na podstawie indywidualistycznej, która była naszej młodzieży wtłaczana w szkole i na ambonie [...], jest [...] teoretycznie nie do utrzymania", ale także - lub przede wszystkim - alternatywna propozycja niemieckiego

5 A. von Hildebrand, Dusza lwa. Biografia Dietricha von Hildebranda (1889-1977), thum. J. Franczak, Warszawa-Ząbki 2008, s. 80. Ta pozycja została wybrana w celu zarysowania portretu Schelera jako człowieka, gdyż z jednej strony nie zmusza do selektywnego doboru faktów biograficznych stawiających myśliciela w negatywnym świetle, $\mathrm{z}$ drugiej zaś została napisana z perspektywy przyjacielskiego sentymentu, a więc nie miała na celu szkalowania jego opinii.

6 A. von Hildebrand, Dusza lwa ..., dz. cyt., s. 102, 104.

A. von Hildebrand, Dusza lwa ..., dz. cyt., s. 120.

A. von Hildebrand, Dusza lwa ..., dz. cyt., s. 125.

9 „Die Moral bloßer Pflicht, Arbeit, Pünktlichkeit, Gesetzlichkeit auf individualistischer Grundlage, die unserer Jugend [...] bisher gelehrt und gepredigt wurde, ist nicht nur theo- 
uczonego. Pozostaje jedynie antropologia, która może jeszcze ewentualnie uzasadnić dychotomię między biograficznymi realiami a teoretycznymi aspiracjami.

\section{Poszukiwania antropologiczne}

Dorobek Maxa Schelera, pomimo wielu modyfikacji jego poglądów, historycy filozofii zgodnie umieszczają w obrębie myśli fenomenologicznej Edmunda Husserla. „Chociaż do swej koncepcji fenomenologii doszedł niezależnie od Husserla (osobiście poznał go dopiero w 1901 r.), to jednak wiele mu zawdzięczał, a w szczególności dzielił z nim podstawowe metodologiczne założenia tej orientacji. Były to: postulat bezzałożeniowości filozofii, wymagający jej niezależności od potocznego poglądu na świat, jak i od rezultatów nauk szczegółowych, oparcia filozofii na szeroko rozumianym doświadczeniu, wreszcie na nastawieniu badawczym mającym na celu odsłonięcie istoty badanego zjawiska" ${ }^{10}$.

Na podkreślenie zasługuje jednak jego podejście do filozofii, znacząco odmienne od prezentowanego przez prekursora ruchu fenomenologicznego. „Stanowili z Husserlem typy umysłu zupełnie odmienne: Husserl stawiał zagadnienia z teoretycznej, on zaś głównie z praktycznej filozofii. Husserl myślał bardzo abstrakcyjnie, on zaś bardzo konkretnie. Husserl był racjonalistą, a Scheler intuicjonistą. Husserl budował filozofię o charakterze ponadczasowym, on zaś związaną z aktualnymi problemami swego czasu. Husserl ulegał nielicznym tylko wpływom, on zaś bardzo wielu i bardzo różnorodnym" ".

Zarówno ilościowa, jak i merytoryczna rozległość spuścizny Schelera nie pozwala na łatwą percepcję jego antropologii. Otwarta pozostaje kwestia, czy z powodu zmienności poglądów myśliciela w ogóle można stawiać tezę o jednej filozofii człowieka, czy jest ich może kilka, począwszy od reprezentowanej przez pierwsze dzieło Der Formalismus in der Ethik und die materiale Wertethik po zawartą w Die Stellung des Menschen im Kosmos. Nie ulega natomiast wątpliwości, że tematyka antropologiczna była dla Schelera ważna ${ }^{12}$.

retisch unhaltbar". M. Scheler, Christentum und Gesellschaft, półtom 1, Konfesionnen, Leipzig 1924, s. 165.

10 W. Stróżewski, Przedmowa, w: M.M. Baranowska, Bóg w myśli Schelera, Kraków 2011, s. 5. Odnośnie do heterogenicznej proweniencji Schelera: por. także A.R. Prokop, Eurofilozoficzny kontekst katolickich konwersji pośród fenomenologów, w: Edyta Stein. Europa i jej tożsamość, red. J. Machnacz, T. Marcinów, K. Serafin, Wrocław 2017, s. 55, przyp. 22.

11 W. Tatarkiewicz, Historia filozofii, t. 3, dz. cyt., s. 301; por. także: J. Galarowicz, Max Scheler, dz. cyt., s. 8-9.

12 Por. M. Scheler, Der Formalismus..., dz. cyt.; M. Scheler, Die Stellung des Menschen im Kosmos, Darmstadt 1928; A. Zimmermann, Der Mensch in der modernen Philosophie, Essen 1975, s. 11. 
Niemiecki uczony zdawał sobie sprawę, że jemu współcześni funkcjonują w potrójnym dorobku kulturowym, który stanowią: wyniki badań nauk przyrodniczych, grecka tradycja myślenia racjonalnego oraz judeochrześcijańska koncepcja religijna. Dla każdej z nich widział też miejsce w swojej antropologii, obejmującej odpowiednio cielesność, inteligencję oraz dążenie do absolutu. Jednakowoż wizja człowieka prezentowana przez każdą $\mathrm{z}$ tych proweniencji pozostaje odmienna, a w punkcie wyjścia nawet nie ma związku z innymi. Za fenomen łączący je wszystkie oraz stanowiący wyznacznik człowieczeństwa Scheler uznaje ducha (niem. Geist), który to termin posiada bogatą tradycję $\mathrm{w}$ idealizmie niemieckim, da się także pogodzić $\mathrm{z}$ okcydentalną tradycją religijną, a w perspektywie biologicznej argumentem pozostaje otwartość na świat odróżniająca homo sapiens od innych zwierząt, które na poziomie instynktu pozostają silnie związane ze swoim biotopem tudzież rewirem. Owego ducha można uznać także za czynnik porządkujący byt jednostkowy, scalający fizyczność, psychiczność i duchowość jednej osoby ${ }^{13}$.

Punktem wyjścia do rozważań Schelera jest perspektywa nastawienia naturalnego. Kierując się nią, myśliciel wykazuje istotne rozróżnienia dotyczące sfery intymnej i społecznej człowieka. Przy czym tylko sfera społeczna może być dzielona ze zbiorowością. Co ciekawe, na podstawie ówczesnych wyników badań, które poświadczały stosunkowo późny rozwój świadomości u dzieci, sformułowano także tezę o uprzednim charakterze zbiorowości w stosunku do samoświadomości indywiduum. Myśliciel, uznawany przez niektórych za twórcę współczesnej antropologii filozoficznej, nie widział w niej gotowych rozwiązań poszczególnych problemów, natomiast chciał „pedagogicznie traktować” innych poprzez formułowanie wyznaczników postaw, które miały pomóc w odkrywaniu i umacnianiu samoświadomości człowieka ${ }^{14}$.

Nie sposób natomiast zignorować głosów aż nadto krytycznych, że antropologia niemieckiego uczonego to niespójna synteza, niespełniająca odautorskiego wymogu bezzałożeniowości, z czasem coraz bardziej opierająca się na heteroge-

13 Por. M.M. Baranowska, Bóg w myśli..., dz. cyt., s. 68-77; J. Brejdak, Fenomen wczucia wedtug Maxa Schelera i Edyty Stein, w: Edyta Stein. Fenomenologia getyńsko-monachijska. Analizy, red. J. Machnacz, K. Serafin, Wrocław 2015, s. 190; J. Galarowicz, Max Scheler, dz. cyt., s. 26-31; G. Mazur, Struktura bytowa człowieka w ujęciu Maxa Schelera, „Colloquia Theologica Ottoniana” 1 (2015), s. 89-106; M. Scheler, Die Stellung..., dz. cyt., s. 13-93; G. Scherer, Strukturen des Menschen. Grundfragen philosophischer Anthropologie, Essen [1976], s. 113-120; M. Uliński, Scheler, Max, art. cyt., s. 443-444; C. Valverde, Antropologia filozoficzna, tłum. G. Ostrowski, Poznań 1998, s. 44-46, 89, 148 151; P. Węcławik, Antropologia filozoficzna Maxa Schelera: jej geneza, przedmiot i metoda, „Folia Philosophica” 16 (1998), s. 107; A. Zimmermann, Der Mensch..., dz. cyt., s. $13-25$.

14 Por. J. Brejdak, Fenomen wczucia..., dz. cyt., s. 190; J. Galarowicz, Max Scheler, dz. cyt., s. 30-32; M. Uliński, Scheler, Max, art. cyt., s. 444; C. Valverde, Antropolologia filozoficzna..., dz. cyt., s. 13, 53-54; P. Węcławik, Antropologia filozoficzna..., dz. cyt., s. 112. 
nicznych postulatach filozoficznych. Ponadto pojawia się zarzut, że Scheler uprawia swoistą fenomenologię idoli i złudzeń, w której niektóre tezy są wprawdzie pieczołowicie budowane, pozostają jednak nieuzasadnione z punktu widzenia metody fenomenologicznej. W perspektywie niniejszego przyczynku, a także osobistych ambicji omawianego w nim myśliciela dążącego do tego, by teoria odzwierciedlała się w praktyce, wszelkie postulaty odpowiedzialności, poczytalności czy też miłości - zakładanej już na poziomie poznawczym - muszą prowadzić do konkluzji, że antropologię niemieckiego uczonego, podobnie jak jego aksjologię i etykę, można uznać za abstrakcyjny teoremat lub pustosłowie, gdyż nie wyjaśnia, a tym bardziej nie uzasadnia dychotomii między teorią a praktyką ${ }^{15}$.

\section{Poszukiwania bibliograficzne}

Zmienność poglądów, tendencja do publikowania raczej krótkich form wydawniczych oraz curriculum vitae coraz bardziej odbiegające od zapatrywań własnych myśliciela - to wszystko prowokuje do pytania o opus magnum. Skoro ostatnie, zaplanowane, wieńczące całą twórczość dzieło nie powstało, tak aby w odniesieniu do niego móc skonfrontować ostateczne ideały z życiem ich wyznawcy, kwestią dyskusyjną pozostaje to, do którego należy się odnieść, skoro całość pozostaje niespójna, a nawet niekiedy wewnętrznie sprzeczna. W niniejszym artykule wybór padł na cytowaną już monografię, której pełny tytuł brzmi: Der Formalismus in der Ethik und die materiale Wertethik. Neuer Versuch der Grundlegung eines ethischen Personalismus, czyli w wolnym thumaczeniu: Formalizm w etyce i materialna etyka wartości. Nowa próba położenia podwalin pod personalizm etyczny ${ }^{16}$.

Cytowany uprzednio biogram encyklopedyczny opatruje to wczesne, choć jedno z obszerniejszych dzieło opublikowane w latach 1913-1918, które do dzisiaj nie zostało w całości przetłumaczone na język polski, atrybutem „główny”, co pozwala się domyślać, że było ono ważne, jeśli nie najważniejsze w spuściźnie Schelera. Ponadto zawiera ono najpełniejszy zarys aksjologii, sformułowanej podobno wbrew wszelkiemu subiektywizmowi i relatywizmowi, ale także wbrew innemu myślicie-

15 Por. M.M. Baranowska, Bóg w myśli..., dz. cyt., s. 123-136; J. Brejdak, Fenomen wczucia..., dz. cyt., s. 189-193; J. Galarowicz, Max Scheler, dz. cyt., s. 26-33, 95-117; M. Scheler, Wolność, miłość..., dz. cyt., s. 79-87; C. Valverde, Antropologia filozoficzna..., dz. cyt., s. 55; P. Węcławik, Antropologia filozoficzna..., dz. cyt., s. 112; A. Węgrzecki, Scheler, Max, art. cyt., s. 942.

16 Por. J. Galarowicz, Max Scheler, dz. cyt., s. 33-44; G. Mazur, Struktura bytowa ..., dz. cyt., s. 90; M. Uliński, Scheler, Max, art. cyt., s. 444; W. Tatarkiewicz, Historia filozofii, t. 3, dz. cyt., s. 301; C. Valverde, Antropologia filozoficzna..., dz. cyt., s. 44, 54-55. Doniosły wpływ na wybór tej określonej pozycji miał także wykład H. Benisza zatytułowany Homo philosophicus na rozdrożu, wygłoszony w semestrze zimowym 2019/2020 dla doktorantów filozofii Uniwersytetu Opolskiego. 
lowi niemieckiemu, Imanuelowi Kantowi (1724-1804), którego wizja człowieka hołubi rzekomo egoizm oraz hedonizm ${ }^{17}$.

Trójpodział proweniencji antropologicznej uczonego da się rozpoznać już w omawianym, stosunkowo wczesnym dziele. Człowiek jest więc zgodnie z tradycją grecką stworzeniem rozumnym, potrafi zatem racjonalnie uporządkować wyniki badań nauk przyrodniczych, do których można znaleźć odwołania na wielu stronicach monografii. Jednakowoż wszystkie te rozważania są umieszczone w jednoznacznej perspektywie judeochrześcijańskiej, gdyż dla myśliciela homo sapiens pozostaje stworzeniem na obraz Boga. Nie dziwi to w kontekście informacji biograficznej, zgodnie z którą niemiecki uczony pisze swoją książkę, w okresie gdy uchodzi za zaangażowanego katolika ${ }^{18}$.

Wybrane dzieło Schelera często bywa przywoływane ze względu na dokonany w nim opis oraz podział wartości. Jest to niewątpliwie temat przewodni monografii, ale już w tym kontekście może zastanawiać postulat relatywizacji ocen etycznych: „Wartość tego praktycznego zachowania jest całkowicie względna w odniesieniu do danego «etosu» i nie może być nigdy mierzona według etosu innej epoki lub innego ludu. Dopiero po ujarzmieniu etosu określonego czasu możemy jakoś osądzać działania i wzorce zachowań człowieka doń przynależnego [...]"19. Powyższa relatywizacja, jak również postulat odróżniania etyki zwyczajowej od filozoficznej stawiają zawartą tam definicję cnoty w zupełnie innym świetle: „Jeśli dane jest to, co (w idealnym przypadku) «powinno być zrobione», i jest to także dane jako «to, co się potrafi», wtedy wynika z takiego stanu rzeczy termin «cnoty». Cnota jest bezpośrednio przeżywaną mocą kardynalną, by uczynić to, co powinno zostać uczynione" ${ }^{20}$. W tak nakreślonej przestrzeni antropologicznej nie istnieją fakty i oceny, a jedynie przypuszczenia oraz interpretacje, gdzie każda kanalia ma możliwość wykpienia się z odpowiedzialności etycznej wymówką o braku umiejętności albo wychowania nieprzystającego do standardów.

17 Por. J. Galarowicz, Max Scheler, dz. cyt., s. 33-44; M. Scheler, Der Formalismus..., dz. cyt., s. 247; A. Węgrzecki, Przedmowa..., dz. cyt., s. 8; A. Węgrzecki, Scheler, Max, art. cyt., s. 941.

18 Por. M. Scheler, Der Formalismus..., dz. cyt., s. 109-161, 260, 297-301; A. Węgrzecki, Scheler, Max, art. cyt.; A. Zimmermann, Der Mensch ..., dz. cyt., s. 11; por. też przyp. 13.

19 „Der Wert dieses praktischen Verhaltens ist ganz und gar relativ auf das jeweilige «Ethos» und kann niemals am Ethos einer anderen Epoche oder eines anderen Volkes gemessen werden. Erst nach Bemächtigung des Ethos einer Zeit können wir Handlungen und Verhaltensweisen eines ihr angehörigen Menschen irgendwie beurteilen [...]”. M. Scheler, Der Formalismus..., dz. cyt., s. 310.

${ }^{20}$ „Ist ein als (ideal) «gesollt» Gegebenes auch unmittelbar als ein «Gekonntes» gegeben, so entspringt aus diesem Tatbestand der Begriff der «Tugend». Tugend ist die unmittelbar erlebte Mächtigkeit, ein Gesolltes zu tun”. M. Scheler, Der Formalismus..., dz. cyt., s. 209. Postulat rozróżnienia etyki filozoficznej i zwyczajowej: M. Scheler, Der Formalismus..., dz. cyt., s. 64. 
Niemiecki autor wiele stron poświęca dookreśleniu pojęcia osoby, ale jest to raczej negatywne oddzielenie od uprzedmiotowienia. Wprawdzie w polskich opracowaniach można znaleźć definicję ,[...] osoba nie powinna być przemyślana jako rzecz czy substancja. Osoba jest raczej bezpośrednio współprzeżytą jednością przeżywania, nie jakąś pomyślaną rzeczą poza tym, co bezpośrednio przeżyte"21. Jednakże w oryginale opatrzono ją zastrzeżeniami, że „wolno tak pomyśleć”, a jej jestestwo określono jedynie negatywnie, podczas gdy stwierdzenie pozytywne ogranicza się do lakonicznego ,jakkolwiek nie dałoby się jej [osoby] bytu ując" wyraźnie i dobitnie się sprzeciwia, nie proponując jednak przekonującej alternatywy. Wprawdzie wartości w jego ujęciu pozostają obiektywne, lecz emocjonalne zabarwienie ich poznania sprawia, że wszelkie formy życia wspólnotowego stają się przeciwieństwem synekury ${ }^{23}$.

Na zakończenie poszukiwań bibliograficznych obszerny cytat, który mógłby poniekąd wyjaśniać rozbieżność przekonań etycznych i zachowań, choć na pewno ich nie usprawiedliwia: „Jest taki stan, który językowo nazywa się «skupienie», tzn. skoncentrowane bycie w sobie - niejako «głębokie życie w sobie». Tu jest tak, jak gdyby całe życie duszy, także to z przeszłości, zebrane zostało w jedno i funkcjonuje jako jedno; to są rzadkie chwile - na przykład doniosłych decyzji lub działań [...]. Nie jesteśmy przy tym puści, lecz całkiem «pełni» $\mathrm{i}$ «bogaci». Tu prawdziwie jesteśmy «ze sobą», «W sobie». Własna cielesność jest przy tym dana jako coś, co do tej skoncentrowanej totalności «przynależy» i nad czym [ta ostatnia] może sprawować «władzę» i panować. [To, co cielesne] jest równocześnie dane jako «tylko teraźniejsze» i jako byt chwilowy, włączone jako część egzystencji danej «na stałe». Każda obecna wówczas kwestia cielesności wydaje się przy tym poniekąd «przepływać» obok owej trwającej egzystencji. Zupełnie odwrotna, fenomenalna, fundamentalna zależność zachodzi między danym ja a daną cielesnością w stanach, które są dla powyżej opisanych przeciwstawne, a jednak mają coś wspólnego, mianowicie to, że niejako «żyjemy w naszym ciele». (Tak na przykład przy dużym, narzucającym się znużeniu czy zmęczeniu, przy silnym odrętwieniu, podczas okresowych uniesień dzięki płytkim przyjemnościom i «rozproszeniom» itd.). Tutaj zmienia się poziom przeżywania naszej egzystencji [...]. Tamże, gdzie uprzednio wszystko było «pełne», jest teraz «puste» [...]. Tutaj zjawisko jest wybitnie jasne, gdyż wówczas to, co jest czysto psychiczne, co jeszcze jest dane i obecne, uzyskuje wrażenie «spływania»; tak jak gdyby myślenie, odczuwanie itd. były zaledwie «nikłym ruchem», który «przebiega» przez głowę i ciało; ciało [...] nie jest wtedy dane jako «tylko

${ }^{21}$ J. Galarowicz, Max Scheler, dz. cyt., s. 31; A. Węgrzecki, Struktura człowieka w ujęciu Maxa Schelera, „Studia Filozoficzne” 15 (1971), nr 6 (73), s. 57.

22 Por. M. Scheler, Der Formalismus ..., dz. cyt., s. 384-387. Przytaczane frazy w oryginale brzmią: „gedacht werden darf” (s. 385); oraz „wie immer ihr Sein sonst genauer zu fassen sei” (s. 386).

${ }^{23}$ Por. J. Galarowicz, Max Scheler, dz. cyt., s. 27-44; A. von Hildebrand, Dusza lwa..., dz. cyt., s. 120; C. Valverde, Antropologia filozoficzna ..., dz. cyt., s. 241-242, 367. 
chwilowo» obecne, jako «nasza własność», «poddana naszej władzy», wręcz przeciwnie, jest lub wydaje się samo naszym ja, zarazem tym stałym, trwającym, nieustannie wypełniającym nasz czas czymś, obok czego przepływa to, co psychiczne, jako to, co «efemeryczne»" 24 .

Nie dziwi w powyższych refleksjach fakt, że Scheler dla jednego stanu medytacyjnego skupienia zna wiele różnorodnych sytuacji antagonistycznych. Niewątpliwie jest to sytuacja współgrająca z danymi biograficznymi. Może to wszakże osłabić siłę podstawowej tezy niniejszego przyczynku, gdyż da się ją pod pewnymi względami zakwalifikować do gatunku ad personam. Kwestią interpretacji naukowej między przyzwoitością a rzetelnością jest postawienie pytania, jaką osobą był moralista o aspiracjach do wytyczania zasad ogólnoludzkich. Zarzut, że ja psychiczne (duch?) nie dominowało $\mathrm{w}$ życiu myśliciela nad ja cielesnym, nabiera w pewnym momencie wymiaru merytorycznego. Stąd cały aksjologiczny oraz etyczny teoremat niemieckiego myśliciela może wydać się czymś ulotnym, podczas gdy fakty biograficzne będą bezspornymi dowodami przeciw efemerycznym danym bibliograficznym, gdyż przecież papier się nie rumieni. Zwłaszcza że nie chodzi tu o fakty zebrane podczas obserwacji ani o metodologicznie sformułowane cele, lecz o subiektywną ocenę (by nie napisać przeżywanie lub doświadczanie) pewnego zjawiska, jakim

24 „Es gibt einen Zustand, den die Sprache «Sammlung» nennt, d.h. konzentriertes Insichsein - gleichsam «tief Leben in sich». Hier ist es, als sei unser ganzes seelisches Leben, auch das der Vergangenheit, in eins zusammengefasst und als eines wirksam; es sind seltene Momente - z.B. von großen Entscheidungen und Handlungen [...]. Wir sind nicht leer dabei, sondern ganz «voll» und «reich». Hier sind wir wahrhaft «bei uns», «in uns» [...]. Die eigene Leiblichkeit ist dabei gegeben als ein Etwas, das jener konzentrierten Totalität «gehört» und worüber sie «Macht» und Herrschaft ausüben kann. Sie ist Gleichzeitig gegeben als «nur gegenwärtig» und als Momentansein, das in eine «dauernd» gegebene Existenz als Teilmoment eingeschloßen ist. Der jeweilige Inhalt der Leiblichkeit scheint dabei an dieser dauernden Existenz gleichsam «vorüberzufließen». Ein völlig umgekehrtes phänomenales Grundverhältnis dagegen besteht zwischen Ich- und Leibgegebenheit in Zuständen, die dem vorher beschriebenen entgegengesetzt sind und die das Gemeinsame haben, das wir gleichsam «in unserem Leibe leben». (So z.B. bei großer, sich aufdrängender Mattigkeit und Müdigkeit, bei starker Erschlaffung, im zeitweisen aufgehen in leeren Genüssen und «Zerstreuungen» usw.). Hier wechselt das Niveau unserer Erlebnisexistenz [...]. Ebenda, wo es vorher «voll» war, ist es jetzt «leer [...]. Hier ist das Phänomen ungemein klar, das nunmehr das rein Psychische, was noch gegeben und da ist, dem Anschein eines «Abfließens» gewinnt; es ist dann als wäre denken, fühlen usw. nur eine «kleine Bewegung», die durch den Kopf und Leib «hindurchzieht»; der Leib [...] ist nun nicht «unser eigen» und unserer «Macht unterworfen» da auch nicht als «nur momentan» gegeben, sondern er ist oder scheint unser Ich selbst zu sein und zugleich als das Feste, Dauernde kontinuierlich die objektive Zeit erfüllende Etwas, an dem das psychische als das «Flüchtige» vorüberfließt”. M. Scheler, Der Formalismus..., dz. cyt., s. 436-437. 
był człowiek, Max Scheler, w konfrontacji z rozumieniem człowieka w antropologii Maxa Schelera ${ }^{25}$.

\section{Zakończenie}

W jednym z opracowań ze wskazaniem na źródło w osobie niemieckiego uczonego znajduje się myśl, że człowiek jest jedyną istotą zdolną do autorefleksji, co jednak nie znaczy, że z tej zdolności korzysta. Owa autorefleksja nie musi być słuszna, gdyż każde doświadczenie pozostaje pośrednie, a przecież od poznania, nawet bazującego na miłości, nie można wymagać całkowitości. Niemniej jednak trudno oprzeć się wrażeniu, że omawiany myśliciel nie potrafił, ani nawet nie chciał wprowadzać własnych idei w życie codzienne. Być może wiązałoby się to jednak z pedagogicznym potraktowaniem samego siebie. Niemniej jednak postulaty i teorie niemieckiego uczonego można uznać za ponadczasowe. Jednakże żaden postęp nie powinien ich czytelnika omamić na tyle, by zapomniał, że myśliciel, na jakimkolwiek błąkałby się bezdrożu, ma prawo, a nawet powinien formułować postulaty etyczne, aksjologiczne bądź antropologiczne. Prawo to jest jednak warunkowe, gdyż biografia własna autora powinna $\mathrm{w}$ takim wypadku stanowić jeden $\mathrm{z}$ probierzy tychże postulatów. Być może jeden z wielu, a czasami - tak jak w przypadku niniejszego przyczynku - pierwszy, a zarazem ostatni. W świecie pełnym hipokryzji łatwo przeoczyć dysonans pomiędzy niepełnością poznania a wykorzystywaniem jej do usprawiedliwienia własnych słabości. Ponadczasowość idei przy całej rozbieżności interpretacji, ale bez krytycznego osądu ich twórcy ignoruje pytanie o ukryte motywacje takich czy innych poglądów. Gdy za doniosłym dziełem etycznym stoi wątpliwa moralnie postać, stanowi to uzasadniony powód do relatywizacji danych poglądów. Na zakończenie, parafrazując wypowiedź samego Schelera, wypada tylko zauważyć, że jest on myślicielem całkowicie i bez reszty problematycznym ${ }^{26}$.

${ }_{25}$ Por. A. Schopenhauer, Die Kunst recht zu behalten, Berlin 2019, s. 38; M. Scheler, Der Formalismus ..., dz. cyt., s. 437. Nawiązanie do słów Cycerona stanowi podkreślenie ponadczasowego bezwstydu w życiorysie Schelera; por. M.T. Cicero, Epistularum ad familiares, ks. V, za: http://www.thelatinlibrary.com/cicero/fam5.shtml\#5 [dostęp: 11 II 2020 r.].

${ }^{26}$ Por. P. Węcławik, Antropologia filozoficzna..., dz. cyt., s. 112; A. Węgrzecki, Przedmowa ..., dz. cyt., s. 8; A. Zimmermann, Der Mensch ..., dz. cyt., s. 11. Parafraza odnosi się do zdania w thumaczeniu Adama Węgrzeckiego (1937-2018): „,człowiek całkowicie i bez reszty stał się «problematyczny»". M. Scheler, Pisma z antropologii filozoficznej i teorii wiedzy, tłum. A. Węgrzecki, Warszawa 1987, s. 151. 


\section{Bibliografia}

\section{Źródla drukowane}

Scheler M., Christentum und Gesellschaft, półtom 1, Konfesionnen, Leipzig 1924.

Scheler M., Der Formalismus in der Ethik und die materiale Wertethik. Neuer Versuch der Grundlegung eines ethischen Personalismus, Halle a.d. Saale 1916.

Scheler M., Die Stellung des Menschen im Kosmos, Darmstadt 1928.

Scheler M., Pisma z antropologii filozoficznej i teorii wiedzy, tłum. A. Węgrzecki, Warszawa 1987.

Scheler M., Wolność, miłość, świętość, tłum. G. Sowiński, Kraków 2004.

\section{Opracowania}

Baranowska M.M., Bóg w myśli Schelera, Kraków 2011.

Brejdak J., Fenomen wczucia wedtug Maxa Schelera i Edyty Stein, w: Edyta Stein. Fenomenologia getyńsko-monachijska. Analizy, red. J. Machnacz, K. Serafin, Wrocław 2015, s. 186-196.

Cicero M.T., Epistularum ad familiares, ks. V, http://www.thelatinlibrary.com/cicero/fam5.shtml\#5 [dostęp: 11 II 2020 r.].

Galarowicz J., Max Scheler, Kraków 2019.

Hildebrand A. von, Dusza lwa. Biografia Dietricha von Hildebranda (1889-1977), tłum. J. Franczak, Warszawa-Ząbki 2008.

Mazur G., Struktura bytowa człowieka w ujęciu Maxa Schelera, „Colloquia Theologica Ottoniana" 1 (2015), s. 89-106.

Prokop A.R., Eurofilozoficzny kontekst katolickich konwersji pośród fenomenologów, w: Edyta Stein. Europa i jej tożsamość, red. J. Machnacz, T. Marcinów, K. Serafin, Wrocław 2017, s. 50-63.

Scherer G., Strukturen des Menschen. Grundfragen philosophischer Anthropologie, Essen [1976].

Schopenhauer A., Die Kunst recht zu behalten, Berlin 2019.

Tatarkiewicz W., Historia filozofii, t. 3, Historia XIX w. i wspótczesna, Warszawa 1950.

Uliński M., Scheler, Max, w: Filozofowie wspótcześni. Leksykon, red. J. Szmyd, Bydgoszcz-Kraków 2003, s. 440-444.

Valverde C., Antropologia filozoficzna, tłum. G. Ostrowski, Poznań 1998.

Węcławik P., Antropologia filozoficzna Maxa Schelera: jej geneza, przedmiot i metoda, „Folia Philosophica” 16 (1998), s. 103-113.

Węgrzecki A., Scheler, Max, w: Powszechna encyklopedia filozofii, t. 8, red. A. Maryniarczyk, Lublin 2007, s. 941-943. 
Węgrzecki A., Struktura człowieka w ujęciu Maxa Schelera, „Studia Filozoficzne” 15 (1971) nr 6 (73), s. 45-62.

Zimmermann A., Der Mensch in der modernen Philosophie, Essen 1975.

\section{Streszczenie}

Artykuł stanowi retrospekcję zaznajamiania się z postacią oraz myślą uznanego intelektualisty, Maxa Schelera (1874-1928), pioniera fenomenologii, etyki oraz antropologii filozoficznej. Artykuł przechodzi od syntezy biograficznej, z uwypukleniem problematycznych elementów życiorysu niemieckiego filozofa, poprzez próbę syntezy dorobku umysłowego w świetle różnorodnych opracowań, których myśl uczonego się doczekała, do krytycznej analizy nieprzetłumaczonego do dzisiaj w całości na język polski dzieła Der Formalismus in der Ethik und die materiale Wertethik (1916). Przedmiotem refleksji pozostaje intuicyjny dysonans pomiędzy tym, co Scheler pisał i głosił, a tym, jak żył, natomiast jej celem jego wykazanie. Wydaje się to zagadnieniem ważkim, zwłaszcza w kontekście etyki i aksjologii, które roszczą sobie prawo do formułowania zasad wiążących dla każdego człowieka.

Słowa klucze: M. Scheler, etyka, aksjologia

\section{Getting to Know Scheler}

\section{Summary}

The article is a retrospective look at the process of getting to know the life and work of a well-known German intellectual Max Scheler (1874-1928), a pioneer in phenomenology, ethics, and philosophical anthropology. The paper covers a biographical synthesis with an emphasis put on the problematic elements of the life of the German philosopher, an attempt to synthesize Scheler's intellectual achievements in the light of various publications devoted to his works and ideas, and a critical analysis of his work entitled Der Formalismus in der Ethik und die materiale Wertethik (1916), which up to this day has not been fully translated into Polish. The subject of this reflection is to show the intuitive dissonance between what Scheler wrote and taught and how he lived, while its purpose is to demonstrate it. This seems to be an important issue, especially in the context of ethics and axiology that claim to have the right to formulate rules binding on every individual.

Key words: M. Scheler, ethics, axiology 